\title{
Perbezaan Sikap dan Kecenderungan Tingkah Laku Pencarum Kumpulan Wang Simpanan Pekerja (KWSP) terhadap Penamaan Wasi ${ }^{1}$
}

\author{
Differences in Attitude and Behavioural Tendency of Employees Provident Fund (EPF) \\ Contributors towards Executor Nomination
}

MOHD MUSA SARIP* \& MOHD MUSTAFFA MOHD JUSOH @ YUSOFF²

\begin{abstract}
The purpose of this article is to identify the differences in attitude and the tendency of the Employees Provident Fund (EPF) contributors in nominating wasi (executor) based on factors such as monthly income, level of education and marital status. This is an exploratory study that utilizes questionnaire as the research instrument. A total of 566 Muslim EPF contributors in Selangor have been selected as the research samples (purposive). Data are processed and analyzed using IBM statistical software, SPSS version 20. The attitudes towards the nomination of executor have been identified to include three elements namely; the attitude in the appreciation of goodwill, the attitude towards the sense of responsibility and attitude in the technical sense. However, the tendency in action or behaviour is represented by one element only. The findings show that there is a difference between attitudes and tendency in the nomination of executor among Muslim contributors with regard to marital status. The findings also show that there is a significant difference in attitude among the contributors with regard to monthly income while for the tendency of action there is a significant difference with regard to the level of education. Contributors who are already married have a more positive attitude towards the nomination of executor and they indicate a higher tendency to nominate executor compared to contributors who are still single. This could be influenced by the contributors' experience and sources of information that they are exposed to, in addition to other factors such as having children and experiencing an unstable level of health.
\end{abstract}

Keywords: executor, pension fund, testament, wasi, will, wisayah

Sistem pelantikan wasi merupakan suatu kaedah yang digunakan bagi memudahkan urusan pentadbiran harta seseorang selepas kematiannya. Sistem ini telah menjadi amalan di Kumpulan Wang Simpanan Pekerja (KWSP) sejak sekian lama sama ada untuk yang beragama Islam atau bukan Islam. Amalan pelantikan wasi tiada dinyatakan di dalam Akta Kumpulan Wang Simpanan Pekerja 1991 tetapi penjelasan kuasa mengadakan sistem penamaan ada disebutkan secara umum.

\footnotetext{
${ }^{1}$ Part of this article has been published in the Proceedings of the $1^{\text {st }}$ International Conference on Management and Muamalah 2014 ( $1^{\text {st }}$ ICoMM) by the Faculty of Management and Muamalah, Kolej Universiti Islam Antarabangsa Selangor.

${ }^{2}$ Mohd Musa Sarip*(Corresponding author), Ph.D., lecturer at the Dept. of Syariah, Faculty of Syariah and Law, Kolej Universiti Islam Antarabangsa Selangor, 43000 BANGI, Selangor, Malaysia, email: mmusa@kuis.edu.my; Mohd Mustaffa Mohd Jusoh @ Yusoff, Ph.D., lecturer at the Dept. of Syariah, Faculty of Syariah and Law, Kolej Universiti Islam Antarabangsa Selangor, 43000 BANGI, Selangor, Malaysia, email: musjusoh@kuis.edu.my.
}

https://10.24035/ijit.12.2017.004 
Penjelasan tambahan berkaitan penamaan ada disebutkan dalam peraturan-peraturan dan kaedahkaedah KWSP sebagai panduan kepada pencarum beragama Islam dan bukan Islam. Secara khusus, Seksyen 9(2) dalam Peraturan-Peraturan KWSP 2001 memperincikan bahawa penama bagi pencarum KWSP yang beragama Islam adalah dianggap wasi atau pentadbir harta dan harta penama merupakan harta pusaka si mati. Seksyen ini juga selari dengan keputusan fatwa peringkat kebangsaan yang telah dikeluarkan pada tahun 1973 dan 2000.

\section{Pelantikan Wasi Menurut Perspektif Islam}

Dalam tasawur Islam, pelantikan wasi merupakan salah satu amalan yang dituntut ke atas umat Islam untuk dilaksanakan dalam muamalat kehartaan khususnya. Wasi atau pentadbir harta merupakan individu yang dilantik menerusi konsep wisoyah dengan pemberian amanah yang dipertanggungjawabkan untuk melaksanakan sesuatu perkara selepas kematiannya (Ezani Yaakub 2006). Kepentingan melantik wasi dapat dilihat melalui pensyariatannya menerusi al-Qur'an, alSunnah dan amalan para sahabat yang menunjukkan keutamaan dan menjanjikan ganjaran pahala dalam melaksanakannya. Allah (s.w.t.) berfirman yang bermaksud:

Kamu diwajibkan, apabila seseorang dari kamu hampir mati, jika ia ada meninggalkan harta, (hendaklah ia) membuat wasiat untuk ibu bapa dan kaum kerabat dengan cara yang baik (menurut peraturan agama), sebagai suatu kewajipan atas orang-orang yang bertaqwa (Surah al-Baqarah 2:180).

Selain itu, agama Islam adalah agama bersifat kasih sayang, cintakan kebajikan dan tolong menolong serta menolak kemudaratan. Maka ia menyeru setiap umat Islam melakukan amalan yang boleh membantu insan lain untuk memperoleh manfaat dan kebajikan pada muamalat kehartaan yang ditinggalkan selepas kematiannya. Firman Allah (s.w.t.) yang bermaksud:

Dan hendaklah kamu bertolong-tolongan untuk membuat kebajikan dan bertaqwa, dan janganlah kamu bertolong-tolongan pada melakukan dosa (maksiat) dan pencerobohan. Dan bertaqwalah kepada Allah, kerana sesungguhnya Allah Maha berat azab seksaNya (bagi sesiapa yang melanggar perintahNya) (Surah al-Ma'idah 5:2).

Perkara ini dikuatkan lagi dengan amalan para sahabat melantik wasi sebelum mereka bermusafir khususnya sebelum pergi berperang antaranya Saidina Uthman, al-Miqdad dan Abdul Rahman bin Auf telah membuat wisoyah dengan melantik Zubair Ibn al-Awwam untuk menjaga harta dan memberi nafkah kepada anak-anak mereka. Selain itu, tujuan wasi di lantik dalam kalangan para sahabat adalah untuk melunaskan hutang, mengembalikan barang pinjaman serta memelihara waris yang ditinggalkan. Begitu juga dalam peperangan Muktah, Rasulullah s.a.w. telah mengamanahkan Zaid bin Harithah supaya memegang bendera. Sekiranya sesuatu berlaku kepada Zaid, maka ia diganti oleh Ja'far, kemudian kepada Abdullah bin Rawahah jika Ja'far gugur (Naziree bin Md Yusof 2008). Hal ini dianggap penting kerana semasa peperangan adalah melibatkan risiko yang tidak dijangka, maka langkah berwaspada adalah amat perlu bagi memastikan kesinambungan muamalat kerhataan khususnya itu terus berjalan.

Oleh itu, beberapa kepentingan melantik wasi sebagai pentadbir harta selepas berlaku kematian ialah dapat memudahkan dan mempercepatkan urusan pengagihan harta pusaka kepada waris-waris yang ditinggalkan. Proses pengagihan harta pusaka akan mengambil kira perkara- 
perkara yang berkaitan dengan hutang-piutang si mati sama ada hutang kepada Allah dan hutang kepada manusia, membahagikan hak-hak harta sepencarian pasangan serta menunaikan wasiat sekiranya ada sebelum pengagihan harta dilakukan secara faraid. Selain itu, mampu menunaikan hajat pemilik harta dan mengelakkan berlakunya tuntutan harta tertunggak kerana melibatkan prosedur-prosedur dokumen tuntutan yang rumit dan berbeza serta mengambil masa yang agak lama (Jasni Sulong 2011).

\section{Amalan Pelantikan Wasi Dalam Kumpulan Wang Simpanan Pekerja}

Dalam konteks pelantikan wasi di KWSP, didapati penglibatan pencarum terhadap pelaksananaan sistem pelantikan ini masih di peringkat yang rendah (Jasni Sulong 2011). Menurut laporan oleh KWSP, pada tahun 2003 hanya kira-kira 30.8 peratus iaitu 3.2 daripada 10.4 juta hali sahaja yang telah membuat pelantikan terhadap caruman masing-masing (News Straits Time 9 November 2003). Manakala menurut Hizwani Hassan dalam nukilan Suhaida Abu Bakar (2010) pada tahun 2009 pula dicatatkan masih sekitar 30 peratus sahaja yang telah mempunyai penama berbanding lebih 11 juta pencarum KWSP yang berdaftar. Didapati juga sehingga Oktober 2012 hanya seramai 3.4 juta daripada lebih 13 juta pencarum KWSP mempunyai penama iaitu dianggarkan hanya 26 peratus pencarum yang telah menamakan penama ke atas wang simpanan persaraan mereka (Farizan Kamaluddin 2012).

Secara teorinya, fenomena pelantikan wasi yang rendah adalah disebabkan oleh beberapa faktor antaranya sikap dan kecenderungan tingkah laku terhadap penulisan dokumen wasiat (Muhamad Muda et al. 2008; Suhaili Alma'amum 2010). Amalan berwasiat merupakan suatu akad muamalah kehartaan yang penting adalah wajar untuk diterokai secara komprehensif dan menyeluruh. Kajian-kajian lalu tentang sikap dan kecenderungan tingkah laku terhadap berwasiat dan juga wisoyah terutamanya berdasarkan aspek demografi adalah kurang dan terbatas. Oleh yang demikian, kajian ini adalah bertujuan untuk mendalami pengaruh demografi ke atas sikap dan kecenderungan tingkah laku terhadap amalan pelantikan wasi dalam kalangan pencarum KWSP beragama Islam. Adakah sikap dan kecenderungan tingkahlaku terhadap amalan pelantikan wasi terdapat perbezaan yang signifikan berdasarkan faktor pemboleh ubah tidak bersandar pendapatan bulanan, tahap pendidikan dan status perkahwinan yang berbeza? Hasil kajian ini diharapkan dapat memberi kefahaman yang menyeluruh tentang pengaruh pendapatan bulanan, tahap pendidikan dan status perkahwinan terhadap sikap dan kecenderungan tingkah laku terhadap pelantikan wasi yang sebenar.

Dalam Teori Tindakan Beralasan oleh Ajzen dan Fishbean (1980), menjangkakan bahawa sikap mampu mendorong seseorang untuk bertingkah laku. Sikap merupakan suatu keadaan persediaan bagi kelakuan atau pendirian untuk bertindak terhadap objek sikap seperti bertingkah laku. Satu aspek lain yang wujud dalam sikap juga adalah kuasa motivasi atau desakan yang terdapat dalam sikap terhadap kelakuan. Kuasa desakan ini dapat mempengaruhi tingkah laku seseorang (Mohd Salleh Leban 1994). Manakala menurut Ajzen (2005), sikap merupakan penilaian menguntungkan (favorable) atau tidak menguntungkan (unfavorable) seseorang terhadap sesuatu objek sikap yang khusus. Sikap yang positif terhadap sesuatu tingkah laku akan menghasilkan kesediaan yang positif dan seterusnya mendorong kepada pelaksanaan tingkah laku tersebut. Oleh itu, sikap terhadap pelantikan wasi ini mengandungi tiga eleman iaitu sikap penerimaan kebaikan, sikap bertanggungjawab dan sikap teknikal yang berkaitan dengan sistem pelantikan wasi di KWSP.

Sikap dan kecenderungan tingkah laku yang positif dijangka memberikan kesan motivasi yang baik untuk melaksanakan pelantikan wasi. Oleh itu, pelantikan wasi benar-benar dapat dilakukan jika seseorang mempunyai sikap yang positif. Manakala, faktor pendapatan bulanan, 
tahap pendidikan dan status perkahwinan pula merupakan pemboleh ubah luaran (external variables) yang dipercayai mempunyai hubungan secara tidak langsung terhadap sesuatu tingkah laku kerana kesannya terhadap kecenderungan tingkah laku didapati tidak konsisten. Namun faktor pendapatan bulanan, tahap pendidikan dan status perkahwinan mempunyai hubungan yang signifikan ke atas sikap dan terhadap sesuatu tingkah laku (Ajzen \& Fishbean 1980).

Berdasarkan kepada kajian-kajian yang telah dijalankan dalam aspek penulisan dokumen perancangan harta perwarisan, didapati bahawa sikap dan kecenderungan tingkah laku terhadap penulisan dokumen tertentu mempunyai hubungan yang signifikan dengan faktor demografi seperti kajian oleh Rowlingson dan McKay (2005), Horkey (2009), Suhaili Alma'amun (2012) dan Horkey dan Hayhoe (2007). Kajian oleh Suhaili Alma'amun (2012) mendapati bahawa faktor pendidikan bukanlah faktor yang mempengaruhi tahap keingingan untuk memiliki wasiat dalam kalangan masyarakat Islam. Begitu juga, kajian yang dilakukan oleh Horkey (2009) mendapati tidak terdapat hubungan yang signifikan antara tahap pendidikan dengan keinginan untuk membuat wasiat dalam kalangan masyarakat Virginia, Amerika Syarikat.

Begitu juga, kajian yang dijalankan oleh Suhaili Alma'amun (2012) mendapati bahawa pendapatan seseorang mempunyai pengaruh yang signifikan. Hasil kajian menunjukkan 70 peratus responden yang mempunyai pendapatan antara RM 1,001 hingga RM RM 4,999 mempunyai wasiat berbanding hanya 17 peratus responden yang mempunyai wasiat dengan pendapatan RM 1,000 ke bawah.

Seterusnya, kajian yang dilakukan oleh Brooker (t.th) mendapati bahawa orang berkahwin, janda atau duda lebih suka untuk memiliki dokumen wasiat berbanding orang yang masih bujang. Kajian yang dijalankan oleh Palmer et al. (2006) juga memperolehi bahawa hubungan sikap terhadap tahap kesihatan dengan penulisan dokumen wasiat berhubungan secara signifikan berdasarkan status perkahwinan. Mereka yang sudah bercerai iaitu kematian pasangan didapati lebih suka untuk mempunyai dokumen wasiat berbanding mereka yang dalam perkahwinan. Walau bagaimanapun, hasil kajian yang dilakukan oleh Suhailim Alma'amun (2012) mendapati sebaliknya iaitu tiada perbezaan yang signifikan diperolehi di antara mereka. Selain itu, kajian yang dilakukan oleh Horkey (2009) juga mendapati tidak terdapat hubungan yang signifikan antara status perkahwinan dengan keinginan untuk membuat wasiat dalam kalangan masyarakat yang berumur 50 tahun ke atas.

Oleh itu, tiga faktor pemboleh ubah tidak bersandar iaitu pendapatan bulanan, tahap pendidikan dan status perkahwinan pencarum telah dipilih dalam kajian ini. Kajian ini bertujuan untuk mendapat kefahaman tentang perbezaan sikap dan kecenderungan tingkah laku terhadap pelantikan wasi dalam kalangan pencarum KWSP berdasarkan kategori pendapatan bulanan, tahap pendidikan dan status perkahwinan yang berbeza. Persoalan kajian ini adalah seperti berikut:

1. Apakah terdapat perbezaan sikap terhadap pelantikan wasi yang signifikan berdasarkan pendapatan bulanan pencarum?

2. Adakah terdapat perbezaan tahap kecenderungan tingkah laku terhadap pelantikan wasi yang signifikan berdasarkan pendapatan bulanan pencarum?

3. Apakah terdapat perbezaan sikap terhadap pelantikan wasi yang signifikan berdasarkan tahap pendidikan pencarum?

4. Adakah terdapat perbezaan kecenderungan tingkah laku terhadap pelantikan wasi yang signifikan berdasarkan tahap pendidikan pencarum?

5. Apakah terdapat perbezaan sikap terhadap pelantikan wasi yang signifikan berdasarkan status perkahwinan pencarum? 
6. Adakah terdapat perbezaan kecenderungan tingkah laku terhadap pelantikan wasi yang signifikan berdasarkan status perkahwinan pencarum?

\section{Metodologi Kajian}

Kajian ini merupakan tinjauan yang menggunakan soal selidik untuk memperolehi profil pendapatan, pendidikan dan status perkahwinan pencarum serta persepsi mereka terhadap sikap dan kecenderungan tingkah laku ke atas pelaksanaan pelantikan wasi di KWSP. Sampel kajian dipilih menggunakan kaedah persampelan bertujuan (purposive) dengan mengambil kira kajian ini merupakan penerokaan awal dalam bidang wasiat atau pun wisoyah serta sampel yang terpilih merupakan pencarum KWSP yang beragama Islam di negeri Selangor (Neuman 2000). Jumlah keseluruhan sampel ialah seramai 556 orang yang terdiri daripada 217 orang lelaki dan 339 orang perempuan.

Data kajian ini dikumpulkan dengan menggunakan instrumen borang soal selidik. Item-item soal selidik dibahagikan kepada tiga bahagian, iaitu bahagian (a) adalah demografi responden, bahagian (b) sikap terhadap pelantikan wasi dan bahagian (c) kecenderungan tingkah laku terhadap pelantikan wasi. Bahagian (a) mempunyai tiga item, manakala bahagian (b) pula mempunyai 13 item dan bahagian (c) terdapat empat item keseluruhannya. Pemboleh ubah sikap dan kecenderungan tingkah laku diukur dalam bentuk skala likert iaitu sangat tidak setuju (1) tidak setuju (2), tidak pasti (3), setuju (4) dan sangat setuju (5). Ujian Cronbach Alpha digunakan untuk menentukan indeks kebolehpercayaan instrumen kajian. Nilai Cronbach Alpha bagi kedua-dua instrumen adalah tinggi. Bagi instrumen sikap terhadap pelantikan wasi kebolehpercayaan Cronbach Alpha adalah 0.887. Manakala nilai Cronbach Alpha bagi instrumen kecenderungan tingkah laku adalah 0.900. Menurut Hair et al. (2006), kebolehpercayaan instrumen yang baik berdasarkan nilai Cronbach Alpha 0.70 atau lebih menunjukkan bahawa item-item adalah konsisten dengan konsep yang diukur dan boleh dipercayai.

Data kajian dianalisis menggunakan statistik deskriptif dan inferensi. Statistik deskriptif digunakan untuk melihat perbezaan skor min sikap dan kecenderungan tingkah laku berdasarkan pendapatan, tahap pendidikan dan status perkahwinan pencarum. Manakala, statistik inferensi iaitu analisis ujian-t dan ANOVA sehala digunakan untuk mengenal pasti sama ada terdapat perbezaan yang signifikan dijangkakan boleh mempengaruhi sikap dan kecenderungan tingkah laku dalam kalangan pencarum Muslim KWSP. Analisis data menggunakan program perisian Statistik IBM SPSS versi 20.

\section{Dapatan Kajian}

Bahagian ini pula melihat sama ada terdapat perbezaan yang signifikan dari segi sikap pelantikan wasi dan dorongan sosial berdasarkan pendapatan bulanan, tahap pendidikan dan status perkahwinan ditetapkan. Bahagian ini akan menjawab persoalan kajian apakah terdapat perbezaan sikap terhadap pelantikan wasi yang signifikan berdasarkan pedapatan bulanan pencarum KWSP? Hasil analisis ANOVA sehala seperti dalam Jadual 1 di bawah. Keputusan ujian ini mendapati nilai $p$ adalah signifikan $(\mathrm{F}(3,552)=3.717, \mathrm{p}=0.01, \mathrm{p}<0.05)$ bagi pemboleh $u$ bah tahap sikap responden. Oleh itu, keputusan ini menunjukkan bahawa terdapat perbezaan yang signifikan sikap terhadap sistem penamaan wasi dalam kalangan responden berdasarkan pendapatan bulanan yang berbezabeza. 
JADUAL 1: $\quad$ Keputusan Ujian ANOVA sehala bagi Perbezaan Sikap Berdasarkan Pendapatan Bulanan

\begin{tabular}{lccccc}
\hline Punca Variasi & JKD & $\mathrm{dk}$ & MKD & F & Sig. p \\
\hline Sikap Terhadap Sistem Penamaan Wasi & & & & & \\
Antara Kumpulan & 2.343 & 3 & .781 & 3.717 & $.011^{*}$ \\
Dalam Kumpulan & 115.984 & 552 & .210 & & \\
Jumlah & 118.327 & 555 & & & \\
\hline
\end{tabular}

*Signifikan pada aras $\mathrm{p}<0.05$

Bagi menentukan pendapatan bulanan yang manakah berbeza serta menyumbang kepada perbezaan ini, ujian post-hoc Scheffe telah dilaksanakan seperti dalam Jadual 2 di bawah. Hasil ujian post-hoc menunjukkan bahawa perbezaan signifikan bagi sikap responden terhadap sistem penamaan wasi disumbangkan oleh pendapatan responden RM 1500.00 ke bawah sebulan ( $\min =4.02$, s. $\mathrm{p}=0.44$ ) dengan pendapatan responden RM 1501.00 hingga RM 3000.00 sebulan (min=4.16, s. p=0.48). Responden berpendapatan RM 1501.00 sehingga RM 3000.00 lebih bersikap positif terhadap sistem penamaan wasi berbanding responden berpendapatan RM 1500.00 ke bawah.

JADUAL 2: Hasil Ujian Post-Hoc Scheffe bagi Perbezaan Sikap Terhadap Penamaan Wasi Berdasarkan Pendapatan Bulanan

\begin{tabular}{lllll}
\hline Pendapatan & Pendapatan & $\begin{array}{l}\text { Perbezaan } \\
\text { Min }\end{array}$ & Ralat Piawai & Sig. p \\
\hline Kurang dari RM1500 & RM1501 - RM3000 & $-.137^{*}$ & .046 & .003 \\
& RM3001 - RM5000 & -.080 & .051 & .483 \\
& RM5001 ke atas & -.193 & .088 & .186 \\
RM1501 - RM3000 & Kurang dari RM1500 & $.137^{*}$ & .046 & .003 \\
\hline
\end{tabular}

*Signifikan pada aras $\mathrm{p}<0.05$

Analisis seterusnya melihat perbezaan berdasarkan pendapatan bulanan bagi pemboleh ubah kedua iaitu kecenderungan tingkah laku penamaan wasi. Hasil analisis ANOVA sehala seperti dalam Jadual 3 di bawah. Hasil ujian ini mendapati nilai p adalah tidak signifikan $(F(3,552)=2.616$, $\mathrm{p}=0.050, \mathrm{p}>0.05$ ) bagi pemboleh ubah tahap kecenderungan tingkah laku penamaan wasi di KWSP. Oleh itu, keputusan ini menunjukkan bahawa tidak terdapat perbezaan yang signifikan tahap kecenderungan tingkah laku penamaan wasi berdasarkan di antara responden yang berpendapatan kurang RM 1500.00 ( $\min =4.03$, s.p = 0.50), RM 1500.00 hingga $\mathrm{RM} 3000.00(\mathrm{~min}=4.15$, s.p = 0.54), RM 3001 hingga RM $5000.00(\min =4.19$, s.p = 0.56) dan RM 5001 ke atas $(\min =4.13, \mathrm{~s} . \mathrm{p}=$ $0.54)$.

JADUAL 3: Keputusan Ujian ANOVA sehala bagi Perbezaan Tahap Kecenderungan Tingkah Laku Penamaan Wasi Berdasarkan Pendapatan Bulanan

\begin{tabular}{|c|c|c|c|c|c|}
\hline Punca Variasi & JKD & $\mathrm{dk}$ & MKD & $\mathrm{F}$ & Sig. p \\
\hline \multicolumn{6}{|l|}{ Kecenderungan Tingkah Laku } \\
\hline Antara Kumpulan & 2.273 & 3 & .758 & 2.616 & .050 \\
\hline Dalam Kumpulan & 159.885 & 552 & .290 & & \\
\hline Jumlah & 162.159 & 555 & & & \\
\hline
\end{tabular}

*Signifikan pada aras $\mathrm{p}<0.05$ 
Persoalan kajian kedua, apakah terdapat perbezaan sikap terhadap pelantikan wasi yang signifikan berdasarkan tahap pendidikan pencarum KWSP? Untuk mengenal pasti persoalan kajian di atas, ujian ANOVA sehala telah dilaksanakan seperti dalam Jadual 4 di bawah. Hasil ujian ini mendapati nilai $p$ yang tidak signifikan $(F(4,551)=0.533, p=0.712, p>0.05)$ bagi pemboleh ubah tahap sikap terhadap sistem penamaan wasi berdasarkan kategori pendidikan yang berbeza. Oleh itu, keputusan ini menunjukkan bahawa tidak terdapat perbezaan yang signifikan berdasarkan sikap terhadap sistem penamaan wasi mengikut tahap kelulusan pendidikan yang diperoleh dalam kalangan responden. Hal ini kerana skor min sikap terhadap sistem penamaan wasi dalam kalangan responden yang bekululusan SPM ke bawah (min=4.10, s. $\mathrm{p}=0.43)$, STPM (min=4.12, s. $\mathrm{p}=0.41)$, diploma ( $\min =4.05$, s. $\mathrm{p}=0.48)$, sarjana muda $(\mathrm{min}=4.12$, s. $\mathrm{p}=0.44)$ dan sarjana ke atas $(\mathrm{min}=4.12$, s.p=0.46) tiada menunjukkan perbezaan yang nyata.

JADUAL 4: Keputusan Ujian ANOVA Sehala bagi Perbezaan Sikap Terhadap Sistem Penamaan Wasi Berdasarkan Pendidikan

\begin{tabular}{llllll}
\hline Punca Variasi & JKD & $\mathrm{dk}$ & MKD & F & Sig. p \\
\hline Sikap Terhadap Sistem Penamaan Wasi & & & & & \\
Antara Kumpulan & .456 & 4 & .114 & .533 & .712 \\
Dalam Kumpulan & 117.871 & 551 & .214 & & \\
$\quad$ Jumlah & 118.327 & 555 & & & \\
\hline
\end{tabular}

*Signifikan pada aras $\mathrm{p}<0.05$

Ujian ANOVA sehala seterusnya dilaksanakan untuk mengenal pasti sekiranya wujud perbezaan tahap kecenderungan tingkah laku dalam kalangan responden berdasarkan kategori pendidikan yang diperolehi. Hasil analisis ANOVA sehala seperti dalam Jadual 5 di bawah. Hasil ujian ini mendapati nilai $\mathrm{p}$ adalah signifikan $(\mathrm{F}(4,551)=3.749, \mathrm{p}=0.00, \mathrm{p}<0.05)$ bagi pemboleh ubah tahap kecenderungan tingkah laku penamaan wasi berdasarkan tahap pendidikan yang pelbagai dalam kalangan responden. Keputusan ini menunjukkan bahawa terdapat perbezaan yang signifikan tahap kecenderungan tingkah laku penamaan wasi dalam kalangan responden berdasarkan tahap kelulusan pendidikan yang berbeza.

JADUAL 5: Keputusan Ujian ANOVA Sehala bagi Perbezaan Tahap Kecenderungan Tingkah Laku Penamaan Wasi Berdasarkan Pendidikan

\begin{tabular}{llllll}
\hline Punca Variasi & JKD & $\mathrm{dk}$ & MKD & F & Sig. $p$ \\
\hline Kecenderungan Tingkah Laku & & & & & \\
Antara Kumpulan & 4.297 & 4 & 1.074 & 3.749 & $.005^{*}$ \\
Dalam Kumpulan & 157.862 & 551 & .287 & & \\
Jumlah & 162.159 & 555 & & & \\
\hline
\end{tabular}

*Signifikan pada aras $\mathrm{p}<0.05$

Bagi menentukan tahap kelulusan pendidikan yang manakah berbeza serta menyumbang kepada perbezaan ini, ujian post-hoc Tukey HSD telah dilaksanakan seperti Jadual 6. Hasil ujian post-hoc menunjukkan bahawa terdapat perbezaan bagi kecenderungan tingkah laku penamaan wasi disumbangkan oleh responden berkelulusan SPM ke bawah (min=4.04, s. p=0.52) dengan responden berkelulusan sarjana muda $(\min =4.23$, s.p $=0.56)$. Hasil ujian ini juga menunjukkan perbezaan yang signifikan tahap kecenderungan tingkah laku penamaan wasi responden berkelulusan diploma $(\min =4.03, \mathrm{~s} . \mathrm{p}=0.51$ ) dengan responden berkelulusan sarjana muda ( $\min =4.23$, s.p=0.56). Ini bermakna bahawa tahap kecenderungan tingkah laku penamaan wasi bagi 
responden berpendidikan sarjana muda lebih tinggi berbanding responden yang berkelulusan diploma dan SPM ke bawah.

JADUAL 6: Hasil Ujian Post-Hoc Tukey HSD bagi Perbezaan Tahap Kecenderungan Tingkah Laku Penamaan Wasi Berdasarkan Pendidikan

\begin{tabular}{lllll}
\hline Pendidikan & Pendidikan & $\begin{array}{l}\text { Perbezaan } \\
\text { Min }\end{array}$ & Ralat Piawai & Sig. p \\
\hline SPM ke bawah & STPM & -.131 & .083 & .514 \\
& Diploma & .007 & .062 & 1.000 \\
& Sarjana Muda & $-.196^{*}$ & .070 & .045 \\
Dioploma & Sarjana ke atas & -.160 & .071 & .169 \\
Sarjana Muda & Sarjana Muda & $-.204^{*}$ & .067 & .020 \\
& SPM ke bawah & $.196^{*}$ & .070 & .045 \\
& Diploma & $.204^{*}$ & .067 & .020 \\
\hline
\end{tabular}

*Signifikan pada aras $\mathrm{p}<0.05$

Persoalan kajian yang berikutnya, apakah terdapat perbezaan sikap terhadap pelantikan wasi yang signifikan berdasarkan status perkahwinan pencarum KWSP? Hasil analisis ujian-t seperti dalam Jadual 7 di bawah. Hasil ujian ini mendapati nilai $\mathrm{p}$ adalah signifikan dengan nilai $\mathrm{t}=$ 2.877 dan sig $=0.004(\mathrm{p}<0.05)$ bagi pemboleh ubah sikap terhadap sistem penamaan wasi. Dari segi min, menunjukkan bahawa pencarum yang berkahwin $(\min =4.13, \mathrm{~s} . \mathrm{p}=0.45)$ mempunyai sikap yang lebih tinggi berbanding dengan pencarum belum berkahwin $(\min =4.00$, s.p $=0.46)$. Oleh itu, keputusan ini menunjukkan bahawa terdapat perbezaan berkenaan sikap terhadap sistem penamaan wasi dalam kalangan responden berdasarkan status perkahwinan.

JADUAL 7: Keputusan Ujian-t Bagi Perbezaan Tahap Sikap Terhadap Pelantikan Wasi Berdasarkan Status Perkahwinan

\begin{tabular}{lccccc}
\hline Status Perkahwinan & N & Min & S.P & Nilai t & Sig. p \\
\hline Belum Berkahwin & 156 & 4.00 & 0.46 & -2.877 & $0.004^{*}$ \\
Sudah Berkahwin & 400 & 4.13 & 0.45 & & \\
\hline
\end{tabular}

* Signifikan pada aras $\mathrm{p}<0.05$

Analisis persoalan kajian yang terakhir adalah adakah terdapat perbezaan yang signifikan bagi skor min tahap kecenderungan tingkah laku penamaan wasi antara pencarum daripada ketegori status perkahwinan. Hasil analisis ujian-t seperti dalam Jadual 8 di bawah. Keputusan ujian-t ini menunjukkan bahawa terdapat perbezaan yang signifikan kecenderungan tingkah laku penamaan wasi berdasarkan status perkahwinan dengan nilai $t=-3.008$ dan $\operatorname{sig}=0.003) \mathrm{p}<0.05$ ). Manakala dari segi min pula didapati bahawa pencarum yang berkahwin $(\min =4.16$, s.p $=0.54)$ mempunyai kecenderungan penamaan wasi lebih tinggi berbanding pencarum yang belum berkahwin $(\min =4.00$, s.p $=0.52)$. Oleh itu, keputusan ini menunjukkan bahawa terdapat perbezaan yang signifikan tahap kecenderungan tingkah laku penamaan wasi berdasarkan status perkahwinan adalah diterima.

JADUAL 8: Keputusan Ujian-t Bagi Perbezaan Tahap Kecenderungan Tingkah Laku Penamaan Wasi Berdasarkan Status Perkahwinan

\begin{tabular}{llllll}
\hline Status Perkahwinan & N & Min & S.P & Nilai t & Sig. p \\
\hline Belum Berkahwin & 156 & 4.00 & 0.52 & -3.008 & $0.003^{*}$ \\
Berkahwin & 400 & 4.16 & 0.54 & & \\
\hline
\end{tabular}

* Signifikan pada aras $\mathrm{p}<0.05$ 


\section{Perbincangan Dan Rumusan}

Kajian ini bertujuan untuk memahami perbezaan sikap terhadap pelantikan wasi yang sebenar berdasarkan tahap pendapatan bulanan (RM 1500.00, RM 1501.00 hingga RM 3000.00, RM 3001.00 hingga RM 5000.00 dan pendapatan RM 5001.00 ke atas), tahap pendidikan dan status perkahwinan (belum berkahwin dan telah berkahwin) dalam kalangan pencarum KWSP Muslim. Di samping itu juga, kajian ini juga untuk melihat perbezaan tahap kecenderungan tingkah laku terhadap pelantikan wasi turut dijalankan berdasarkan tahap pendapatan bulanan, pendidikan dan status perkahwinan pencarum.

Dapatan kajian menunjukkan terdapat perbezaan yang signifikan bagi sikap dan kecenderungan tingkah laku pelantikan wasi berdasarkan status perkahwinan dalam kalangan responden. Hasil kajian mendapati pencarum yang telah berkahwin mempunyai sikap yang lebih baik dan positif terhadap pelantikan wasi berbanding mereka yang belum berkahwin. Begitu juga, mereka yang telah berkahwin lebih cenderung untuk melantik wasi berkemungkinan mereka senang dan mudah menerima pendapat, nasihat, dorongan dan maklum balas daripada pasangan, ibu bapa, rakan-rakan dan guru agama terhadap pelantikan wasi berbanding sebaliknya. Perkahwainan merupakan suatu pengalaman baru yang mampu membawa kepada perubahan sikap dan keterbukaan menerima pandangan dan cadangan daripada sekeliling mereka. Hasil kajian ini mengesahkan kajian lalu yang dijalankan oleh Brooker (t. th.).

Hasil kajian ini juga menunjukkan bahawa terdapat perbezaan yang signifikan sikap terhadap pelantikan wasi dalam kalangan pencarum yang mempunyai pelbagai tahap pendapatan. Ini memberi makna bahawa kedudukan pendapatan seseorang memberikan kesan yang berbeza. Hal ini didorong oleh tahap kesedaran mereka yang berpendapatan sederhana lebih tinggi untuk melaksanakan sistem pelantikan wasi di KWSP. Pencarum-pencarum yang memiliki tahap pendapatan yang baik kebiasaannya lebih mudah untuk menerima maklumat berkaitan pelantikan wasi kerana mereka sering berurusan dengan pihak KWSP berkaitan skim-skim pengeluaran yang ditawarkan antaranya skim pengeluaran pembelian rumah dan skim pengeluaran pendidikan. Ini secara tidak langsung membolehkan pencarum menerima nasihat dan peringatan oleh pegawai KWSP tentang kepentingan melantik wasi.

Selain itu, hasil kajian ini telah mendapati terdapat perbezaan kecenderungan tingkah laku terhadap pelantikan wasi berdasarkan tahap pendidikan dalam kalangan pencarum. Pencarum yang memiliki ijazah sarjana muda ke atas mempunyai kecenderungan yang lebih baik dan positif berbanding pencarum yang memiliki sijil diploma dan ke bawah. Oleh yang demikian, dapatan kajian ini berbeza dengan kajian yang dilakukan oleh Suhaili Alma'amun (2012) dan Horkey (2009). Hal ini menunjukkan bahawa faktor tahap pendidikan memainkan peranan yang penting dalam melaksanakan sistem pelantikan wasi tersebut. Ini berkemungkinan kesan daripada promosi dan penyebaran maklumat daripada pihak KWSP melalui media sosial lebih mudah untuk difahami dan dihayati. Bahkan, media sosial merupakan saluran yang paling digemari rakyat Malaysia daripada pelbagai peringkat umur untuk mendapatkan maklumat yang tepat dan berkesan.

Kesimpulannya, kajian ini mendapati faktor pendapatan bukanlah indikator kepada perubahan kecenderungan terhadap pelantikan wasi ke atas wang simpanan KWSP. Namun, tahap pendidikan mampu memberikan impak ke atas kecenderungan tingkah laku pelantikan wasi terutamanya ke atas pencarum yang telah berkahwin mempunyai sikap yang lebih positif dan terbuka untuk menerima pandangan dan nasihat dariapada orang lain. Peranan perkahwinan kebiasaannya akan melahirkan zuriat dan berlakunya komunikasi yang baik dan berterusan di antara pasangan mampu mendorong seseorang untuk melantik wasi yang sebenar menurut syariat Islam. Iklim perkahwinan yang sakinah dan mawaddah amat bermakna meningkatkan kesediaan 
pelantikan wasi dalam pentadbiran harta perwarisan yang terancang pada masa hadapan. Justeru, semua pihak perlu bertanggungjawab memainkan peranan dalam mewujudkan alam perkahwinan yang harmoni dan sejahtera di dunia dan di akhirat.

\section{References}

Al-Qur'an.

News Straits Time. 2003. 9 November.

Abdul Aziz Hassan \& Yusmawati Yusop. 2006. Perancangan harta di ZAR Perunding Pusaka Sdn. Bhd. dlm. M. Siti Mashitoh. Harta Amanah Orang Islam di Malaysia Perspektif UndangUndang dan Pentadbiran. (hlm. 149-170). Kuala Lumpur. t.pt.

Ajzen I. 2005. Attitudes, Personality and Behavior (2nd ed.). New York: Open University Press.

Ajzen, I. \& Fishbean, M. 1980. Understanding Attitudes and Predicting Social Behavior. Englewood Cliffs: rintice-Hall.

Ajzen, I. 1991. The theory of planned behavior. Organizational Behavior and Human Dicision Process. $50(2), 179-211$.

Berita Harian. 2010. Elak keluarga bertelingkah rebut pusaka. Amanah Raya Berhad. June 25.

Brooker, S. n.d. Finding the Will: A Report on Will-Writing Behavior in England and Wales. Retrieved August 2013, 12, from National Consumer Council: http://www.simplywills.org/Portals/0/NCCReport_Tracking_Time_Bomb.pdf

Dewan Masyarakat. 2007. hlm. 36. July.

Edwards, K. 1991. Planning for family asset transfers. Financial Counseling and Planning. 2: 55-78.

Ezani Yaakob. 2006. Fiqh Pengurusan Harta Si Mati dan Wasiat: Teori dan Praktis. Shah Alam: Pusat Penerbitan Universiti (UPENA) UiTM.

Farizan Kamaluddin. 2012. Amalan Sistem Pelantikan KWSP. Temubual. December 11.

Fishbein, M. \& Ajzen, I. 1975. Belief, Attitude, Intention and Behavior: An Introduction to Theory and Research: Reading. MA: Addison-Wesley.

Hair, J.F., Black, W.C., Babin, B.J., Anderson., R.E, \& Tatham, R.L. 2006. Multivariat Data Analysis (6th ed.). New Jersey: Pearson Internatinal Edition.

Harian Metro. 2011. Setempat. RM120j harta tak dituntut. hlm. 53A. July 29.

Hizwani Hassan. 2009. Sistem Penama KWSP. Interview. September 6.

Horkey, C. \& Hayhoe, C. 2007. Older adults in Virginia with estate planning. Proceedings of the Association for Financial Counseling, Planning, and, (hlm. 133-142). USA. ???

Horkey, C. 2009. Estate Planning Documents In Virginia Among Adults 50 And Over With At Least One Adult Child. Virginia: Virginia Polytechnic Institute and State University.

Jasni Sulong. 2011. Pembaharuan Undang-Undang Pentadbiran Pusaka Islam. Pulau Pinang: Penerbit Universiti Sains Malaysia.

Kamil Md Idris, \& Ahamd Mahdzan Ayob. 2002. Peranan sikap dalam gelagat kepatuhan zakat pendapatan gaji. Analisis. 9 (1\&2): 171-191.

Mohd Ridzuan Awang. 1994. Undang-undang Tanah Islam: Pendekatan Perbandingan. Kuala Lumpur: Dewan Bahasa dan Pustaka.

Mohd Ridzuan, A. 2008. Pengurusan pusaka dan wasiat orang Islam di Malaysia. Prosiding Konvensyen Kebangsaan Pengurusan Harta Pusaka, Wasiat dan Wakaf (hlm. 1-31). Bangi: Jabatan Syariah, UKM.

Mohd Salleh Lebar. 1994. Asas Psikologi Perkembangan. t.tp.: Utusan Publications Sdn Bhd.

Mueller, D. 1986. Measuring Social Attitudes. New York: Teachers Collage.

https://10.24035/ijit.12.2017.004 
Muhamad Muda, Syahidawati Shahwan \& Norhidayah Ibrahim. 2008. Faktor Penglibatan Muslim dalam Amalan Wasiat: Satu Kajian Awalan. Prosiding Konvensyen Kebangsaan Pengurusan Harta Pusaka, Wasiat dan Wakaf (hlm. 247-262). Bangi: Jabatan Syariah, Universiti Kebangsaan Malaysia.

Narizan Abdul Rahman. 2006. Pentadbiran Harta Amanah Orang Islam: Tinjauan kepada harta penama. Dlm. Siti Mashitoh Mahamood (pnyt.). Harta Amanah Orang Islam di Malaysia (hlm. 209-223). Kuala Lumpur: Penerbit Universiti Malaya.

Naziree Md Yusof. 2008. Hukum Wisoyah \& Realitinya Permasalahnya dalam Konteks Perancangan Pusaka Islam. Jurnal Muamalat. Bil 1.

Neuman, W. 2000. Social Research Methods: Qualitative and Quantitative Approaches. (4th Edition). United States: Pearson.

Oskamp, S. 1991. Attitudes and Opinions. (2nd ed.). Englewood Cliffs: Prentice-Hall.

Ostrom, T. 1969. The relation between the effective, behavioral and cognitive components of attitude. Journal of Experimental Social Psychology. 5: 12-30.

Palmer, L., Bhargava, V., \& Hong, G. 2006. Will adoption and life events among older. Financial Services Review. 15: 281-295.

Ram AlJaffri Saad, Kamil Md Idris \& Zainol Bidin. 2009. Peraturan Pembayaran Zakat Kepada Institusi Zakat: Sikap Peniaga dan Kesannya Terhadap Gelagat Pembayaran Zakat Perniagaan. Jurnal Syariah. 17(3): 607-630.

Suhaida Abu Bakar. 2010. Pelantikan dalam Kumpulan Wang Simpanan Pekerja dan Tabung Haji: Satu kajian menurut undang-undang Islam (Tesis Sarjana). Bandar Baru Bangi: Universiti Kebangsaan Malaysia.

Suhaili Alma'amum. 2010. Islamic Estate Planning: Analysing The Malaysian Perceptions On Wasiyyah (Will) And Bequest Practicies. Tesis PhD: Durham University.

Utusan Malaysia. 2011. RM42b harta dibeku. March 30. 